\title{
ETIKA PROFESI: SEBUAH UPAYA PENGAPRESIASIAN ETIS-FILOSOFIS
}

\author{
Amril $M$
}

\begin{abstract}
Profession ethics in a professional vocation that is something demanded is not only containing moral rules for members and organizers of the certain profession, but also as tools for the wide community to understand and evaluate moral quality of such profession. Furthermore, the most important further is ability to think reflectively-ethics on ethical codes of their profession. Through such of thinking, they will be able to think philosophically-jurisprudence, diligent, and inclusive by reference to religious norms, law, and social setting that can yield moral-ethical behavior and moral wises.
\end{abstract}

Key words: Profession ethics, Ethical-reflective, and moral

$$
\begin{aligned}
& \text { الملخص: الأخلاق المهنية فن الأعمال المهنية التى هى شيئ محتاج، لا تحتوى على قوانين أخلاقية للأعضاء المهنية و }
\end{aligned}
$$

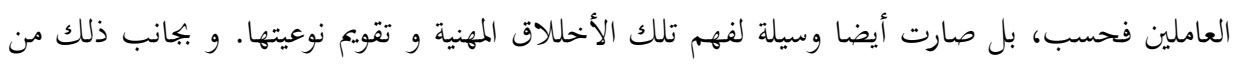

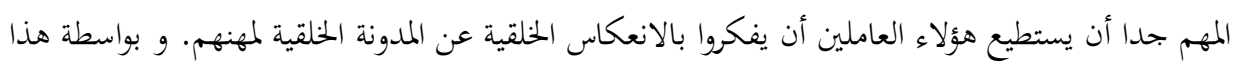

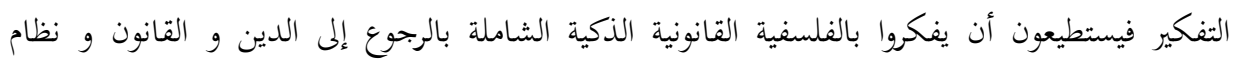

$$
\begin{aligned}
& \text { الاجتماعية الذى يتولد منه السلوك المتخلق بالأخلاق الحسنة الحكيمة. }
\end{aligned}
$$

\section{Pendahuluan}

Pada prinsipnya etika profesi muncul dalam rangka penyempurnaan perilaku kerja ke arah yang lebih baik, paling tidak sesuai dengan yang diharapkan. Dalam hal ini dapat dipahami, bahwa etika profesi merupakan rambu-rambu bagi sekelompok pekerja dalam menunaikan tugas-tugasnya, sedemikian rupa terhindar dari hal-hal yang tidak diinginkan.

Begitu pentingnya etika profesi bagi setiap kelompok kerja untuk mencapai tujuan yang diinginkan, sehingga tidak jarang para pekerja terlihaat kaku dalam memahami etika profesi dengan aturan-arturan yang tertuang dalam kode etik keprofesian mereka, meskipun demikian tidak dinafikan terdapat pelanggaran-pelanggaran. Menyadari adanya sikap baik yang affirmatif maupun yang negatif bagi kelompok pekerja tertentu, maka yang lebih menarik untuk ditelaah secara serius adalah bagaimana menumbuhkan apresiasi yang dinamis dan proforsional terhadap etika profesi yang telah ditetapkan, sehingga akan melahirkan pemahaman yang lebih utuh dan lebih baik diaplikasikan dalam setiap kinerja anggotanya.

\section{Etika Profesi: Makna dan Fungsi}


Etika profesi salah satu aturan yang mengikat individu dalam kelompok kerjanya. Sebagai regulasi, hanya mengenal dua bidang perilaku; perilaku yang sesuai dengan aturan dan yang berlawanan dengan aturan. Meskipun etika profesi berbeda dengan aturan-aturan yang ditemukan dan telah hidup dalam kehidupan sosial masyarakat.

Perbedaan tersebut antara lain terlihat dari saksi yang diberikan, pada aturan-aturan sosial masyarakat, sanksi moral lebih diperankan dan diharapakan dari masyarakat, meskipun dalam kelompok masyarakat tertentu bisa lebih keras dari masyarakat lainnya, namun pada etika profesi tanggung jawab lebih ditumpukan pada otoritas profesi untuk memberikan sanksi terhadap ketentuan yang terakulmulasi dalam kode etik profesi yang telah ditentukan. Artinya, peranan komunitas moral profesi tertentu yang terikat dengan etika profesi tertentu yang paling menentukan.

Secara esensial, etika profesi merupakan prinsip kerja yang mengikat selama seseorang bekerja dalam profesi tertentu dan telah ditampilkan dalam bentuk rincian tugas, tanggungjawab dan hak-hak pekerja. Dalam konteks seperti ini etika profesi dari perspektif telaah etika dapat dimasukkan ke dalam moral rules; yakni aturan moral yang diharapkan dapat melahirkan perilaku moral berdasarkan perintah dan larangan yang dianggap memiliki otoritas untuk aturan-aturan itu. Aturan-aturan moral itu biasanya ditujukan untuk individu maupun kelompok yang menuntut dan menghendaki ketaatan mutlak dari pelakunya. ${ }^{1}$ Karakteristik yang melekat pada etika profesi seperti ini membedakannya dari kebiasaan, adat istiadat, etiket, sopan santun dan moral, ${ }^{2}$ kendatipun diakui posisi nilai dan norma sebagai standar ukur bagi perilaku moral untuk kedua kelompok ini sama-sama berada pada posisi pra moral. ${ }^{3}$

Pada prinsipnya etika profesi dibuat untuk mengatur tingkahlaku moral suatu kelompok dalam masyarakat yang diharapkan akan dipegang teguh oleh seluruh kelompok itu. Sementara profesi secara umum dapat diartikan moral community (masyarakat moral) yang memiliki cita-cita dan nilai-nilai bersama, sehingga setiap individu memiliki posisi yang sama dalam etika profesi. Dengan demikian, profesi menjadi kelompok yang mempunyai kekuasaan dan tanggung jawab tersendiri. ${ }^{4}$

Sesungguhnya dalam praktek kehidupan sehari-sehari terma-terma kebiasaan, adat istiadat, etiket, sopan santun, moral dan etika sering diapresiasi dengan makna yang sama, padahal sesungguhnya dalam kajian filsafat moral terma moral dan teman-temannya dengan terma etika memiliki pemahaman yang berbeda, terutama dari sudut epistemologis-metodologis moral, sedemikian rupa membawa perbedaan pemahaman secara ontologis-aksiologis. K.Bertens mengungkapkan, moral itu adalah nilai dan norma-norma yang menjadi pegangan bagi seseorang atau kelompok untuk mengatur tingkahlakunya. ${ }^{5}$ Hal yang sama diungkapkan oleh Lorens Bagus, bahwa moral menyangkut kegiatan manusia yang dipandang sebagai baik atau buruk, benar 
atau salah, tepat atau tidak tepat, atau menyangkut cara seseorang bertingkahlaku dengan yang lain. ${ }^{6}$ Norma dan nilai ini dalam moral selain sebagai standart normatif bagi pelaku sekaligus juga sebagai perintah untuk berperilaku sesuai dengan norma atau nilai tersebut. ${ }^{7}$ Sedangkan makna etika memiliki cakupan yang lebih luas dan dalam bila dibandingkan dengan muatan makna pada moral seperti disebutkan di atas.

Franz Magnis Suseno mengungkapkan bahwa etika merupakan filsafat atau pemikiran kritis dan mendasar tentang ajaran-ajaran, norma-norma, nilainilai serta kebiasaan dan pandangan moral secara kritis. ${ }^{8}$ Sedemikian rupa, dengan karakteristiknya seperti ini secara eksplisit disebut juga etika sebagai nama lain dari filsafat moral ketika etika itu dijadikan studi filosofis terhadap moral. ${ }^{9}$

Terdapat perbedaan makna yang mendasar pada moral dan etika. Moral memiliki makna tentang bagaimana berperilaku sesuai dengan tuntutan norma atau nilai yang telah diakui, sedangkan etika selain seseorang dituntut untuk berperilaku sesuai dengan norma atau nilai, juga dituntut mampu mengetahui dan memahami sistem alasan-alasan moral serta konsep-konsepnya secara rasional guna mencapai yang terbaik. Dengan kata lain, pada etika berperilaku moral sama pentingnya dengan memahami atau mengapresiasi alasan-alasan norma moral. ${ }^{10}$

Dengan demikian, dapat dikatakan bahwa muatan makna pada etika profesi sesungguhnya menuntut kemampuan untuk merealisasikan perilaku sesuai dengan ketentuan-ketentuan yang telah ditetapkan, namun juga dituntut mampu memahami alasan-alasan dasar ketentuan-ketentuan yang telah ditetapkan tersebut. Dalam konteks seperti inilah semestinya etika profesi dipahami oleh para pelakunya, sehingga peraturan-peraturan yang tertuang dalam suatu kode etik, tidak mesti hanya sebatas imperatif-preskriptif semata, tetapi juga filosofis-sosio-etis. Dengan demikian, tidak menjadikan pelakunya berpikir kaku, sempit dan eksklusif.

Pada prinsipnya kode etik dalam profesi dibuat untuk mengatur tingkahlaku moral kelompok tertentu dalam masyarakat yang diharapkan akan dipegang teguh oleh seluruh kelompok itu. Sementara profesi secara simpel dapat diartikan suatu moral community (masyarakat moral) yang memiliki cita-cita dan nilai-nilai bersama, sehingga setiap individu memiliki posisi yang sama dalam etika profesi. ${ }^{11}$

Mengingat karakteristik profesi seperti diutarakan di atas, menjadikannya sangat mudah terjebak ke dalam eklusivitas, tertutup dan kaku. Karena itu kode etik untuk suatu profesi sangat diperlukan. Hal ini tidak saja sebagai rambu-rambu bagi pelaku kelompoknya, tetapi juga untuk menjamin kualitas suatu profesi di mata masyarakat di luar kelompok itu sendiri. 
Kendatipun kode etik terkelompokkan dan produk etika terapan sebagai hasil penerapan pemikiran etik atas profesi tertentu, bukan berarti pemahaman yang reflektif terhadap kode etik yang telah diformulasikan itu terhenti, karena memang pada prinsipnya dari perspektif etika, kode etik sebagai produk pemikiran etika tidak dapat menggantikan pemikiran etik itu sendiri, akan tetapi yang diinginkan sesungguhnya adalah suatu kode etik mestilah diiringi dengan refleksi etik. Sedemikian rupa kode etik ini dari waktu ke waktu butuh penilaian dan revisi sesuai dengan perkembangan dan desakan masyarakat ke arah yang lebih baik.

Secara individual, tentunya diperlukan pemahaman yang cerdas dari pelaku profesi terhadap kode etik mereka. Dalam hal ini pemikiran kritis dan reflektif sangat diperlukan, sehingga sikap kaku dan eksklusif dari ikatan etika profesi terhadap pelakunya dapat dihindari.

Kecuali untuk kepentingan di atas, berpikir reflektif sangat memungkinkan bagi etika profesi sebagai salah satu bentuk etika terapan bersifat luwes dan fleksibel bagi kebaikan dirinya untuk mengarah pada yang terbaik, terutama bila dikaitkan dengan problema-problema global yang semakin mendesak dalam kehidupan manusia banyak persoalan etik yang boleh jadi tidak terakomodasi dalam kode etik tertentu. Oleh karena itu perlu adanya pemikiran kritis dan dinamis untuk mengapresiasi etika profesi, sehingga benar-benar berimplikasi moral-etis bagi perlakunya.

\section{Berpikir Reflektif-Etis: Sebagai Upaya Peningkatan Apresiasi Terhadap Etika Profesi}

Berpikir reflektif-etis adalah semacam bentuk berpikir yang mengutamakan pemikiran berpandangan ke depan setelah menganalisis plus minus dari berbagai konsekuensi yang mungkin ditimbulkan dari objek yang ditelaah, menuju suatu keputusan yang terbaik dari berbagai pilihan yang tersedia. Mengingat dalam konteks etika penelaahan akan konsekuensi tersebut berkenaan dengan memilah dan memilih mana yang paling bermanfaat dan menguntungkan menuju kebaikan dan kebajikan, maka model pencarian moralitas seperti ini dapat disebut dengan teleologis aksiologis-etis. Dengan demikian yang dimaksud dengan metode berpikir reflektif-etis adalah metode yang lebih menekankan kemampuan akal secara cerdas, menganalisis konsekuensi dan implikasi dari suatu perilaku moral menuju yang terbaik dan terbajik. Melalui metoda berpikir seperti ini seyogyanya penumbuhkembangan perilaku moral tidak saja melulu didasari pada metoda imperatif-normatif semisal pengaplikasian etika profesi an sich, yakni suatu metoda yang menekankan akan larangan dan suruhan yang didasari pada alasan-alasan norma atau aturan yang telah diakui begitu adanya, tetapi juga sudah semestinya diikutkan metoda berpikir reflektif-etis. Sedemikian rupa dengan metoda berpikir seperti ini akan dapat memungkinkan munculnya kesadaran 
moral dari dalam diri individu, sehingga perilaku moral yang ditampilkannya tidak saja atas desakan perintah ajaran atau aturan yang mengikatnya semata, tetapi juga didorang oleh kesadaran dirinya, melalui penelaahan dan pemahaman terhadap konsekuensi dari suatu perilaku yang dilakukannya melalui akalnya secara cerdas dan kritis.

Dari perspektif kajian etika Islam khususnya, perilaku moral yang sesungguhnya atau akhlak adalah perilaku yang tumbuh atas kesadaran paling dalam dari dalam jiwa manusia dan hanya diorientasikan bagi kepentingan kemanusia-an dan ke-Ilahi-an. ${ }^{12}$ Perilaku moral seperti ini sangat mungkin untuk ditampilkan, karena pada prinsipnya, ia merupakan perwujudan akhlak potensial yang telah dianugerahkan Allah SWT pada manusia untuk ditampilkan menjadi akhlak aktual. ${ }^{13}$ Dengan demikian, perilaku moral dalam Islam dalam pengertian yang sesungguhnya adalah suatu kemestian bagi manusia dan sekaligus merupakan kewajiban eksistensial bagi manusia untuk mengembangkan sifat-sifat ke-ilahi-an yang memang telah dianugerahkan oleh Tuhan dalam kehidupan nyata.

Untuk sampai pada perilaku moral atau akhlak seperti ini, selain taat melaksanakan ibadah-ibadah atau ajaran agama yang telah ditentukan, juga terus menerus berupaya memaksimalkan kerja akal tidak saja dalam bentuk halhal yang praktis, tetapi juga dalam hal-hal yang teoritis dan kontemplatif serta menjaga atau mengendalikan jiwa syahwat dan emosi agar tetap berjalan pada jalur naturalnya. ${ }^{14}$

Dari uraian di atas terlihat dengan jelas bahwa selain dengan menunaikan ajaran agama, perilaku moral atau akhlak menuntut pemberdayaan akal secara kritis dan kontempalatif. Pemberdayaan akal seperti ini dapat direalisasikan dengan model berpikir reflektif-etis.

Memperhatikan konsep etika Islam seperti yang telah diungkap di atas menunjukkan bahwa perilaku moral atau akhlak itu lahir dari hasil kerja maksimal akal. Artinya, untuk melahirkan perilaku moral yang sesungguhnya, model berpikir reflektif-etis tidak dapat ditinggalkan, kendatipun Islam tidak menapikan perilaku moral yang lahir atas desakan dari luar dirinya seperti aturan-aturan dan perintah-perintah semisal kode etik dalam suatu profesi. Hanya saja, perilaku moral yang lahir dari bentuk yang terakhir ini, kualitasnya berada di bawah yang pertama dan belum mencapai perilaku akhlak yang sesungguhnya, karena eksistensialitasnya muncul akibat paksaan dari luar dirinya, bukan atas dasar kesadaran atau kewajiban moral dari dalam diri yang merupakan esensi kemanusiaan itu sendiri yang telah dianugerahkan Tuhan kepada manusia.

Berkaitan dengan uraian di atas, seorang praktisi hukum misalnya atau pelaku profesi lain, mestinya tidak mengabaikan berpikir reflektif-etis, paling tidak ketika ia memahami persoalan-persoalan hukum dari dimensi filosofis terhadap profesi yang dilakoninya. Tuntutan seperti ini memang cukup beralasan, paling tidak adanya kecenderungan rasional praktisi hukum yang 
lebih mengembangkan berpikir analitical jurisprudence dari pada philosophical jurisprudence yang mengaitkan persoalan hukum dengan moral dan etika. ${ }^{15}$

Sesungguhnya berpikir reflektif-etis ini juga dapat mengajak para pelaku profesi tertentu untuk membuka dan mengembangkan cakrawala pemikirannya pada hal-hal yang sangat terkait dengan kemuliaan profesinya. Pemikiran seperti ini paling tidak diarahkan pada persoalan-persoalan seperti tuntunan agama, hukum dan tatanan sosial.

Pentingnya agama dalam orientasi pemikiran seperti ini mengingat agama merupakan landasan dasar dalam kehidupan manusia, bahkan dalam perspektif etika Islam, agama menjadi pondasi bagi setiap pemikiran etika dan moral. Kecuali itu, agama memang menjadi kebutuhan dasar dalam diri manusia yang sekaligus merupakan tuntunan bagi kemaslahatan manusia. Demikian pula halnya dengan hukum, mengingat hukum merupakan kristalisasi keinginan masyarakat untuk mewujudkan kehidupannya yang lebih baik. Artinya hukum dalam pengertian seperti ini merupakan suara hati masyarakat untuk menjadi lebih baik secara pasti. Hal yang sama juga pada tatanan sosial, seperti hukum, tatanan sosial juga dimuati oleh berbagai keinginan etis masyarakat guna menata kehidupan mereka ke arah yang lebih baik, kendatipun diakui bahwa tatanan sosial sedikit kurang mengikat ketimbang hukum dan perundangundangan tertulis lainnya, namun bukan berarti implikasi dan konsekuensi moralnya lebih ringan ketimbang produk hukum tertulis lainnya.

Di bawah ini diuraikan secara ringkas peranan tiga tatanan kehidupan di atas dalam upaya meeningkatkan apresiasi etis terhadap etika profesi.

\section{Agama}

Berpikir reflektif-etis ini setidaknya merujuk pada tuntunan agama dan tatanan sosial. Tuntunan agama mutlak diperlukan bagi pengembangan kode etik profesi ini. Alasannya agama dapat memberikan landasan pemikiran dan implikasi moral yang lebih baik. Raghib al-Isfahani dalam hal ini sangat menekankan posisi agama dalam pemikiran dan pembentukan perilaku etik, baik dalam bentuk ajaran agama abkam al-syari ah maupun dalam bentuk makarim al-syariah. ${ }^{16} \mathrm{Hal}$ yang sama juga diungkapkan oleh J.J.Rousseau seorang filsuf Perancis yang hidup dalam era moderen. Menurutnya, agama adalah kumpulan moral, sehingga sangat sulit bagi seseorang untuk bermoral jika ia tidak beragama. ${ }^{17}$ Dengan demikian agama dan ajarannya memegang peranan penting, tidak hanya mampu melahirkan perilaku moral yang searah dengan tuntutan perilaku yang diinginkan oleh etika profesi yang telah ditetapkan dalam profesi tertentu, bahkan dapat memicu tumbuh suburnya perilaku moral tersebut secara mudah dan ikhlas oleh pelaku dari profesi tersebut.

Implementasi praktis dari uraian di atas menjadikan ketaatan pada agama bagi pelaku suatu profesi sangat mutlak diperlukan. Dalam konteks ini dapat 
dipahami bahwa profesionalisme hendaknya seiring dengan ketaatan kepada agama. Orang-orang seperti inilah nantinya yang akan mampu melahirkan pemikiran-pemikiran etis dalam rangka men-dinamisasikan dan mengapresiasikan kode etik profesinya, sekaligus mampu mengaplikasikannya dalam perilaku yatanya.

Dalam perspektif etika Islam, untuk terciptanya manusia-manusia yang mampu berpikir reflektif-etis terhadap kode etik profesinya selain taat menjalankan ajaran agama, juga dengan menfungsikan akal semaksimal mungkin sebagai pengejawantah-an dari berpikir reflektif-etisnya sehingga menjadikannya mampu menetralisir kondisi daya-daya jiwa lainnya seperti daya syahwat dan emosi yang sangat mudah mengganggu pencariannya ke arah kebaikan dan kebajikan dalam menjalankan profesinya. Dengan model upayanya seperti ini akan mudah baginya menuju terbentuknya pemikiran etis dan pengaplikasiannya dalam kehidupan. Tegasnya dengan memaksimalkan kerja akal dalam menggerakkan setiap perilaku etis tentunya menjadikan akal sebagai kata kunci metodologis dalam penumbuhkembangan perilaku etis, akan selalu berorientasi pada nilai-nilai etis di bawah sinaran ajaran agama.

Penempatan akal pada posisi yang demikian memang cukup beralasan. Hal ini tidak saja karena akal sebagai salah satu indikasi adanya moralitas dalam diri seseorang, tetapi secara eksistensial akal mampu melihat berbagai alternatif pilihan sebagai salah satu cara untuk memutuskan suatu perilaku. ${ }^{18}$ Oleh karena itu pemberdayaan akal sebagai basis penumbuhkembang-an perilaku moral yang dipayungi nilai-nilai agama mestilah benar-benar mendapatkan prioritas ketika seseorang meng-apresiasi kode etik profesinya.

Dari uraian di atas dapat dipahami bahwa dengan menerapkan model berpikir reflektif-etis dalam persoalan-persoalan hukum misalnya, menjadikan para praktisi hukum akan selalu konsen terhadap persoalan nilai-nilai moraletis, karena dengan model berpikir seperti ini, praktisi hukum akan selalu ingin mencari tahu apa aksiologis-etis dari setiap persoalan hukum yang tengah di hadapinya, atau persoalan-persoalan moral yang sedang berlangsung di tengahtengah kehidupannya yang terkait dengan keprofesiaannya tanpa mesti menapikan nilai-nilai ajaran agamanya.

Para praktisi hukum seperti ini dengan kecerdasanya akan selalu mencari yang terbaik dari sekian banyak alternatif jawaban yang didapatkannya setelah mempelajari konsekuensi dan implikasi dari suatu persoalan. Artinya dengan model berpikir seperti ini akan lahir kepedulian etis yang amat dalam pada dirinya, lantaran desakan dari dalam dirinya yang telah terbiasa berpikir reflektif-etis yang pada gilirannya akan menuntun setiap perilaku yang ditampilkannya dalam bentuk perilaku moral tanpa mesti distimulasi oleh faktor-faktor eksternal lainnya. Inilah perilaku moral sesungguhnya yang diinginkan dalam perspektif etika Islam seperti telah disinggung dimuka. 
Kecuali pemanfaatan agama sebagai rujukan berpikir kritis bagi praktisi hukum seperti diungkap di atas, perlu juga digaris bawahi, bahwa adanya sifat hukum yang cenderung, baik langsung ataupun tidak langsung, ke arah yang lebih sekuler dan melepaskan diri dari keterkaitan teologis, ${ }^{19}$ akan dapat ditangulangi, paling tidak dikurangi, melalui pengaplikasian tuntunan agama ketika berpikir reflektif- etis seperti ini diterapkan. Pemanfaatan nilai-nilai agama dalam berpikir reflektif-etis ini dapat dilakukan dengan melakukan dialogis normativitas ke-Ilahi-an dengan empiris ke-manusia-an. ${ }^{20}$

\section{Hukum}

Diakui bahwa hukum dan moral merupakan sesuatu yang tidak dapat dipisahkan, namun keduanya tidak pula dapat disamakan. Hukum diadakan memang untuk melahirkan ketenteraman, keharmonisan yang juga muaranya ke arah terciptanya perilaku moral dalam kehidupan individu, kelompok dan masyarakat. Artinya, ketika hukum ditaati, akan lahirlah perilaku moral, sebaliknya ketika hukum diabaikan maka lahirlah perilaku amoral. Dengan demikian dapat dikatakan di sini bahwa, selain pengaplikasian ajaran agama, hukum adalah juga insrumen bagi perwujudan perilaku moral. ${ }^{21}$

Sebagai instrumen moral, tentunya hukum mesti pula didasari pada moralitas, baik pada dimensi pemikiran, maupun pada dimensi aplikatif. Kesadaran pengaktualisasian hukum atau aturan dan seumpamanya pada individu dan kelompok akan sangat tergantung pada kesadaran moral pelakunya. Dengan demikian pendasaran hukum pada moral menjadikan hukum dapat fungsional. Tegasnya fungsionalisasi hukum ke arah yang diinginkan sangat membutuhkan kesadaran moral. Kaisar Romawi pernah berucap, bahwa apa artinya undang-undang kalau tidak disertai moral, ${ }^{22}$ maksudnya bahwa hukum tidak akan berarti banyak dan tidak akan mampu berbuat apa-apa jika tidak dijiwai dengan moral. Kualitas hukum ditentukan oleh kualitas moral. Karena itu, hukum harus senantiasa diukur dengan norma-norma moral. Di pihak lain, moral akan menjadi keinginan normatif an sich jika tidak diungkapkan dan dilembagakan dalam bentuk produk hukum di dalam masyarakat.

Kendatipun hubungan hukum dan moral sangat erat seperti diungkap di atas, namun bukan berarti keduanya identik dan juga tidak berarti semua keinginan moral diundangkan dalam bentuk hukum. Dengan demikian dapat dikatakan pula bahwa hukum tidak dapat mewakili moral secara utuh, karena memang tak dapat disangkal bahwa banyak nuansa moral yang tidak terwakili oleh hukum dan seumpamanya, kendatipun hukum adalah bahagian moral.

Berkaitan dengan uraian di atas seorang praktisi hukum, suka ataupun tidak, mesti tidak mengabaikan berfikir reflekti-etis tentang persoalanpersoalan hukum dari dimensi filosofis-etis. Tuntutan seperti ini memang cukup beralasan, paling tidak adanya kecenderungan profesionalistik praktisi hukum yang lebih berfikir analytical jurisprudence ketimbang philosophical 
jurisprudence seperti telah diungkap di muka, atau lebih mengedepankan logika hukum ketimbang filosofis-sosio-etis. Konsekuensinya tidak jarang pula ditemukan sebagian praktisi hukum menjadi kaku dan sempit ketika memahi persoalan hukum. Hukum hanya dilihat dari dimensi hukum saja, seolah-olah terlepas dari persoalan moral dan etika. Dalam konteks seperti inilah dapat dipahami munculnya perilaku arogan dan profesionalisme ekstrem ditemukan pada sebagian para praktisi hukum kita saat ini yang pada akhirnya merugikan missi mulia hukum itu sendiri.

\section{Tatanan Sosial}

Masyarakat dan aturan-aturan yang hidup di dalamnya memang dapat dijadikan sumber atau rujukan pemikiran dalam merefleksikan pemikiran etis dan menarik kesimpulan etis dalam upaya melahirkan perilaku moral yang lebih baik Bahkan tidak jarang keinginan-keinginan yang bergulir di dalam kehidupan masyarakat juga dapat dijadikan sumber inspirasi dan motivasi pencarian dan perealisasian perilaku moral dan bajik.

Kecuali keberadaan masyarakat seperti diungkap di atas, fungsionalisasi masyarakat bagi penanaman nilai-nilai moral tidak pula dapat dikesampingkan. Hal ini dikarenakan bahwa anak manusia lahir dan dibesarkan di dalam masyarakatnya, sehingga norma-norma moral sebagai pembentuk pemikiran dan perilaku moral praktisnya bersumber dan dibentuk oleh masyarakat dimana ia hidup dan dibesarkan, ${ }^{23}$ kendatipun tidak dapat dikesampingkan bahwa akhir-akhir ini adanya fenomena menipisnya fungsionalitas masyarakat untuk menumbuh-kembangkan perilaku moral semakin dirasakan. ${ }^{24}$

Secara teoritis pada prinsipnya segala produk hukum merupakan kristalisasi dari keinginan etis masyarakat, sedemikian rupa dapat dikatakan pula bahwa masyarakat sesunguhnya merupakan subjek hukum, namun setelah hukum terformalisasikan dalam bentuk institusi legal-formal, seolaholah masyarakat terlupakan sebagai subjek hukum, yang terjadi justru sebaliknya, masyarakat berada pada posisi objek hukum dan tidak jarang menjadi "permainan" hukum. Ini merupakan sesuatu yang amat keliru dan menyedihkan dalam pengembangan hukum ke arah yang lebih fungsional dan berkeadilan.

Perlakuan hukum terhadap masyarakat yang tidak menyenagkan seperti di ungkap di atas semestinya tidak harus dipertahankan keberlangsungannya, karena memang suatu produk hukum lahir dari dan untuk masyarakat, oleh karena itu seyogyanya masyarakat sebagai subjek hukum tidak mesti ditinggalkan dan dilupakan. Sebaliknya, tentu mesti ditumbuh-suburkan dan dijaga akan peranan masyarakat sebagai subjek hukum ini, sehingga keinginan etis masyarakat betul-betul dapat dirasakan oleh masyarakat itu sendiri melalui pruduk hukum yang telah dilegalkan tersebut. 
Implementasi praktis dari keinginan tersebut di atas tentunya social pressure terus dihidupsuburkan dan difung-sionalisasikan. Hal seperti ini cukup beralasan, karena sesungguhnya social pressure itu secara eksistensial dapat dipandang sebagai alat kontrol bagi masyarakat terhadap produk hukum yang merupakan buah dari kristaliasi keinginan etis mereka. Namun amat disayangkan apa yang terlihat saat ini adalah adanya praktek-praktek sekelompok orang, sengaja ataupun tidak, menafikan peranan social pressure ini dari persoalan hukum, atau kuatnya kesan puas pada sebagian masyarakat manakala keinginan-keinginan etis mereka telah terformulasi ke dalam produk hukum, sehingga mereka mengaggap kewajiban mereka untuk merealisasikan keinginan etis mereka dalam kehidupan nyata tidak lagi pada pundak mereka, tetapi pada aparat hukum.

Bagi praktisi hukum, seyogyanya dinamika tatanan sosial dengan segala implikasi dan konsekuensinya yang terjadi di dalam masyarakat, mestilah benar-benar dicermati secara bijak dan cerdas, sehingga akan meningkatkan pengapresiasian etisnya terhadap kode profesi mereka.

Kecuali alasan di atas, juga disadari bahwa para praktisi hukum secara eksistensial merupakan perpanjangan peran masyarakat untuk merealisasikan dan menegakkan keingian etis masyarakat. Oleh karena itu adalah sangat berbahaya dan tidak bijak jika ditemukan adanya sebagian praktisi hukum justru meninggalkan keinginan-keinginan etis masyarakat dengan hanya mengandalkan berpikir dalam bentuk analitik hukum dan berpegang teguh pada logika hukum semata tanpa menoleh sedikit pun pada pesan-pesan nilai etis yang terkandung dalam suatu produk hukum tersebut. Sebaliknya adalah sesuatu yang sangat diinginkan dan bijak jika para praktisi hukum bersedia menoleh secara kritis dan reflektis-etis terhadap dinamika tatanan masyarakat yang juga dapat dinilai sebagai sumber keinginan-keinginan etis masyarakat.

\section{Kesimpulan}

Kuatnya desakan perubahan dalam kehidupan masyarakat sebagai akibat arus globalisasi dan transparansi, menjadikan segala bentuk keinginan etis masyarakat semakin meningkat dan mendesak yang pada gilirannya menuntut pula pada pengembangan dan peningkatan apresiasi etis terhadap tatanan atau aturan-aturan yang terdapat di dalam masyarakat.

Etika profesi sebagai bentuk upaya konkret untuk mewujudkan perilaku moral di dalam suatu profesi tertentu dalam konteks kehidupan sekarang, tentunya menuntut pemahaman yang transformatif-etis bagi pelakunya menuju perilaku terbaik dan bajik demi kemuliaan profesi itu sendiri di mata masyarakat. Untuk itu perlu adanya pengembangan model berpikir bagi pelakunya. 
Model berpikir yang dibutuhkan untuk hal seperti ini adalah reflektif-etis yang mengacu pada ajaran agama, hukum dan tatanan sosial yang hidup di tengah-tengah masyarakat. Sedemikian rupa menjadikan para pelakunya mampu melahirkan perilaku moral yang tidak hanya didesak oleh hukum dan aturan-aturan, tetapi memang dilakukan atas dasar kesadaran dalam diri sehingga melahirkan perilaku moral yang sesungguhnya sebagai bentuk perilaku moral-etis; akblaq.

\section{Catatan Akhir:}

${ }^{1}$ Curt Baier., The Moral Point of View: A Rational Basis of Ethics, Cornell University Press, London, 1969, h. 139

2 Perbedaan keragaman aturan dalam kehidupan masyarakat seperti sopan santun, etiket, aturan adat istiadat, dijelaskan secara komparatif oleh Curt Bayer dalam bukunya The Moral Point of View: A Rational Basis of Ethitcs, Lihat lebih lanjut Curt Bayer, Ibid, h. . 123-126.

${ }^{3}$ Mengingat norma dan nilai serta ajaran-ajaran baik agama maupun "kesepakatan sosial " dari suatu masyarakat tertentu dalam perilaku moral dan etika sebagai standar ukur dalam menentukan suatu perilaku moral sekaligus mengupayakannya tampil dalam perilaku senyatanya, maka menjadikan norma dan kawan-kawannya ini berada pada posisi pra moral. Uraian lebih lanjut untuk hal ini baca misalnya Amril M, "NILAI DAN PENDIDIKAN (Sebuah Upaya Pengaplikasian Nilai dan Norma Dalam Praxis Kependidikan)", makalah disampaikan pada kuliah perdana Filsafat Moral di Prodi PAFI Semester III /S2 Pascasarjana IAIN STS Jambi tanggal 25 September 2003.

${ }^{4}$ K.Bertens, Etika, Gramedia Pustaka Utama, Jakarta, 1994, h. 277-278.

${ }^{5}$ I $b I d$, h. 3-4.

${ }^{6}$ Lorens Bagus, Kamus Filsafat, Gramedia Pustaka Utama, Jakarta, 1996, h. 672.

7 Paul W. Taylor, "Introduction: What is Morality" dalam Paul W. Taylor (ed) Problem of Moral Philosophy An Introduction To Ethics, Dickenson Publishing Company, Inc. California, 1967, h. 3 .

${ }^{8}$ Franz Magnis Suseno, Etika Dasar: Masalah-Masalah Pokok Filsafat Moral, Kanisius, Yogyakarta, 1993, h. 14 dan 18. h. 7.

'Paul W. Taylor, "Introduction: What is Morality" dalam Paul W. Taylor (ed) Op. Cit.,

${ }^{10}$ Amril M., Etika Islam Telaah Pemikiran Raghib al-Ishfahani, Pustaka Pelajar, Yogyakarta, 2002, h. 19.Selanjutnya ditulis Etika...

${ }^{11}$ K.Bertens, Op. Cit., h. 277-278.

${ }^{12} \mathrm{Al}$-Farabi, "Fu ş ūl al-Muntaza`a fí- 'Ilm al-Akhlāq" dalam Majid Fakhry, al-Fikr alIsl'am fi al-'Arabiy, Juz II, D àr al-Fikr, Beirut, 1980, h. 78.

${ }^{13}$ Amril M., Etika....Op. Cit., h. 98-101.

${ }^{14}$ Prosudural epistemologis-metodologis dalam kajian etika Islam guna terbentuknya perilaku moral-etis selain menunaikan dan melaksanakan ajaran-ajaran agama, juga melakukan penyucian jiwa (self-purification0 yaitu dengan selalu membelajarkan daya nathiqah, mengekang daya syahwiyah dan mengendalikan daya ghadabiyah dengan pemain utama pada kemampuan akal. Lihat lebih lanjut Amril M, Etika..., Ibid, h 147-154. Implikasi 
dari teori penyucian jiwa ini terutama dalam kehidupan moderen lihat lebih lanjut Amril $\mathrm{M}$, "Self-Purification Dalam Pemikiran Etika Islam (Suatu Telaah Atas Pemikiran Etika Raghib al-Isfahani dan Refleksinya dalam Mengatasi Qua Vadis Modernitas ) "dalam Al-Fikra, Vol. 1, No. 2, Januari-Juni 2003, Jurnal Ilmiah Keislaman Program Pascasarjana IAIN Sulthan Syarif Qasim Pekanbaru

${ }^{15}$ Henry Hazlitt, Op. Cit, h. 65-66

${ }^{16}$ Ajaran-ajaran agama yang terealisir dalam ibadah-ibadah yang telah ditetapkan begitu adanya yang dikelompokkannya dengan Abkam al-Syari ah akan mampu menghasilkan perilaku moral, sedangkan ajaran-ajaran agama yang ditujukan untuk menyempurakan ajaran agama pada kelompok terdahulu akan mampu pula mengjasilkan perilaku moral. Dalam pemaknaan di atas menurut penulis perilaku moral yang akan dihasilkan oleh Abkam alSyariah merupakan perilaku moral-dogmatis, sedangkan Makarim al-Syariab akan menghasilkan perilaku moral-etis pemahaman lebih lanjut akan dua kategori perilaku moral di atas, terutama dari sisi dasar, implikasi dan implementasinya baca lebih lanjut Amril M, Etika.... Op. Cit, terutama Bab III dan Bab IV.

${ }^{17}$ Muhmidayeli, Pemikiran Etika Ibn Miskawaih dan J.J. Rousseau (Studi Perbandingan Filsafat Moral), Susqa Press, Pekanbaru, 2001, h. 186-187.

${ }^{18}$ Dalam perspektif etika, epistemologi nilai dilihat dari dua sudut, yakni deontologis dan teleologis. Bila deontologis, nilai ditentukan dari perbuatan itu sendiri, sedangkan teleologis, nilai ditentukan oleh konsekuensi dari suatu tindakan moral. Lihat lebih lanjut umpamanya Paul W. Taylor, "Introduction: What is Morality" dalam Paul W. Taylor (ed), Op. Cit, h.213. Lihat juga Nancy Davis (Ann), "Contemporary Deontology" dalam dalam Piter Singer (ed), A Compation to Ethics, Black-Well, New York, 1992, h. 205-206.

${ }^{19}$ Henry Hazlitt.,Op. Cit, h. 64.

${ }^{20}$ Pemahaman lebih lanjut untuk hal seperti ini dapat dilihat dalam Amril M., "Maulud Nabi Muhammad SAW dalam Telaah Strategi Pengembangan Masyarakat Etis -Qur'anik", makalah disampaikan pada acara Peringatan Maulud Nabi Muhammad SAW Tk. I, Propinsi Jambi, tgl 29 Mai 2002. Di Mesjid Agung al-Falah, Jambi. Lihat juga Amril M., "Pendidikan Tinggi Islam dalam Perspektif Dunia Kontemporer (Sebuah Reformulasi Aksi Akademis IAIN Menuju UIN", dalam al-Fikra Jurnal Ilmiah Keislaman, Vol. I. No. I, Agustus-Desember 2002, Program Pascasarjana IAIN Sulthan Syarif Qasim Pekanbaru, h. 72-78.

${ }^{21}$ Dalam memandang hubungan antara hukum dan moral ini paling tidak terdapat dua corak pemikiran. Yang pertama mengatakan bahwa hukum mendahului moral sedangkan yang kedua moral mendahului hukum. Baca lebih lanjut John Rawl "Two Concept of Rulers" dalam Paul W. Taylor (ed), Op. Cit, h. 278-280.

${ }^{22}$ Robert Lee (ed)., A History of Civilization, vol.I, Pretice-Hall Englewood Clifs, New Jersey, 1955, h. 212.

23Pemikiran etika yang menumpukan akan peranan utama masyarakat bahkan satusatunya lembaga penumbuhkembangan sikap dan perilaku moral dalam filsafat moral dikenal dengan istrilah Ethical Relativism. Untuk pemahaman lebih lanjut baca umpamanya tulisan Walter Terence Stace, “Ethical Relativity” dalam Paul W. Taylor (ed), Ibid, h. 52-66.

${ }^{24}$ Kegagalan akan peranan masyarakat sebagai lembaga penumbuhkembangan perilaku moral pada anak saat ini tidak diragukan lagi. Hal seperti ini setidaknya teramati dari semakin demonstratifnya instrumen-instrumen sosial seperti masmesia masa baik elektronik maupun cetak yang mengikis nilai-nilai moral yang selama ini dijunjung tinggi. Uraian sebagian untuk hal seperti ini lihat lebih lanjut Amril M, Moralitas Keagamaan Dalam 
Al-Fikra: Jurnal Ilmiah Keislaman, Vol. 3, No. 2, Juli-Desember 2004

Pendidikan (Sebuah Rekonstruksi Metodologis-Aplikatif di Sekolah) Makalah disampaikan pada Seminar Regional Musabaqah Tilawatil Qur`an Tingkat Provinsi Jambi, 1 Juni 2003 di Kab. Muaro Jambi. Tulisan yang sama dapat juga dilihat pada Jurnal Pemikiran Islam dan Kependidikan AL-TA LIM, Vol. XI. No. 15 , Th. 2004. Fakultas Tarbiyah IAIN Imam Bonjol Padang, h. 74-94. 